\title{
Field surveys and numerical modeling of the August 2016 Typhoon Lionrock along the northeastern coast of Japan: the first typhoon making landfall in Tohoku region
}

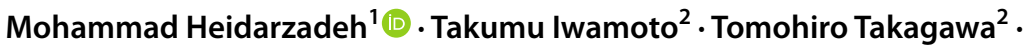 \\ Hiroshi Takagi ${ }^{3}$
}

Received: 23 January 2020 / Accepted: 9 June 2020 / Published online: 20 June 2020

(C) The Author(s) 2020

\begin{abstract}
Typhoon Lionrock, also known as the national number 1610 in Japan, caused severe flooding in east Japan in August 28-31, 2016, leaving a death toll of 22. With a maximum sustained wind speed of $\sim 220 \mathrm{~km} / \mathrm{h}$ from the Joint Typhoon Warning Center's best track, Lionrock was classified as a category 4 hurricane in Saffir-Simpson Hurricane Wind Scale and as a typhoon in Japan Meteorological Agency's scale. Lionrock was among unique typhoons as it started its landfall from north of Japan. Here, we studied the characteristics of this typhoon through tide gauge data analysis, field surveys and numerical modeling. Tide gauge analysis showed that the surges generated by Lionrock were in the ranges of $15-55 \mathrm{~cm}$ with surge duration of 0.8-3.1 days. Our field surveys revealed that the damage to coastal communities/structures was moderate although it caused severe flooding inland. We measured a maximum coastal wave runup of $4.3 \mathrm{~m}$ in Iwaisaki. Such a runup was smaller than that generated by other category 4 typhoons hitting Japan in the past. Our numerical model was able to reproduce the storm surge generated by the 2016 Typhoon Lionrock. This validated numerical model can be used in the future for typhoon-hazard studies along the coast of northeastern Japan. Despite relatively small surge/wave runups in coastal areas, Lionrock's death toll was more than that of some other category 4 typhoons. We attribute this to various primary (e.g., flooding, surges, waves, strong winds) and secondary (e.g., landslides, coastal erosions, debris flows, wind-blown debris) mechanisms and their combinations and interactions that contribute to damage/death during a typhoon event.
\end{abstract}

Keywords Pacific Ocean · Japan · Storm surge · Hurricane · Typhoon Lionrock · Numerical simulations $\cdot$ Field surveys

Mohammad Heidarzadeh

mohammad.heidarzadeh@brunel.ac.uk

https://www.brunel.ac.uk/people/mohammad-heidarzadeh

1 Department of Civil and Environmental Engineering, Brunel University London, Uxbridge UB8 3PH, UK

2 Tsunami and Storm Surge Research Group, Port and Airport Research Institute, Yokosuka 239-0826, Japan

3 School of Environment and Society, Tokyo Institute of Technology, Tokyo 152-8550, Japan 


\section{Introduction}

Extreme coastal flows observed during recent coastal environmental hazards such as tsunamis, hurricanes and typhoons have transformed the knowledge of coastal engineering by revealing the shortcomings of the coastal construction. The past 16 years (2004-2020) has witnessed a series of such extreme events, among which are the 2004 Indian Ocean tsunami (Synolakis and Bernard 2006; Rabinovich and Thomson 2007), the 2005 Hurricane Katrina (Robertson et al. 2007; Fritz et al. 2007), the 2007 Cyclone Sidr (Paul 2009), the 2008 Cyclone Nargis (Fritz et al. 2009), the 2010 Maule (Chile) tsunami (Rabinovich et al. 2013; Mas et al. 2012; Fritz et al. 2011), the 2011 Japan tsunami (Tsuji et al. 2011; Suppasri et al. 2012; Heidarzadeh and Satake 2013a), the 2012 Hurricane Sandy (Irish et al. 2013), 2013 Super Typhoon Haiyan (Shimozono et al. 2015; Takagi et al. 2017), the 2017 Hurricane Maria (Heidarzadeh et al. 2018) and the 2018 Super Typhoon Jebi in Japan (Le et al. 2019). These extreme coastal environmental events produced structural forces far beyond the design loads and caused the structures to fail in novel failure modes. As a result, these events motivated the revision of the coastal design guidelines where new guidelines such as ASCE 7-16 (tsunami loads and effects) (Chock 2016) emerged. This has motivated field surveys of extreme coastal events worldwide to measure wave runup heights and record the damage to infrastructures and failure modes.

Japan coasts are exposed to typhoons and associated storm surges/waves which have caused significant damage and death. Major typhoons affecting Japan coasts in the past century are listed in Table 1 among which are the Typhoon Isewan in 1959 (also known as Vera) in Ise Bay (5098 deaths), the Super Typhoon Tip in 1979 (99 deaths) and the Typhoon Tokage in 2004 ( 69 deaths). Figure 1 shows the tracks of the tropical cyclones

Table 1 Some of the most intensive tropical cyclones and typhoons affecting Japan in the past century and the number of associated deaths

\begin{tabular}{llll}
\hline Storm name (year) & JMA intensity $^{\mathrm{a}}$ & Death toll $^{\text {References }}$ \\
\hline Jebi (2018) & Typhoon & 13 & Le et al. (2019) \\
Lan (2017) & Typhoon & 8 & Islam et al. (2018) \\
Lionrock (2016) & Typhoon & 22 & FDMA (2017) \\
Goni (2015) & Typhoon & 1 & Takagi and Wu (2016) \\
Tokage (2004) & Typhoon & 69 & Esteban and Shibayama (2008) \\
Mireille (1991) & Typhoon & 64 & Takemi et al. (2016) \\
Tip (1979) & Typhoon & 99 & Cerveny et al. (2007) \\
Olga (1970) & Typhoon & 20 & Matano and Sekioka (1971) \\
Isewan (1959) (also known as Vera) & Typhoon & 5098 & Hamuro et al. (1969) \\
Makurazaki (1945) (also known as & Typhoon & $>2000$ & Goda and Hashimoto (1983) \\
$\quad$ Ida) & & & \\
Muroto (1934) & Typhoon & $\sim 3000$ & Tsuchiya and Kawata (1986) \\
Taisho (1917) & Typhoon & $\sim 1300$ & Tatekoji et al. (2017), Hoshino et al. \\
& & & (2015) \\
\hline
\end{tabular}

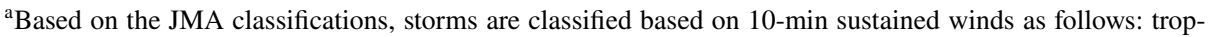
ical depression (wind $<63 \mathrm{~km} / \mathrm{h}$ ), tropical storm $(63<$ wind $<87 \mathrm{~km} / \mathrm{h}$; equivalent to category 1 ); severe tropical storm $(89<$ wind $<117 \mathrm{~km} / \mathrm{h}$; equivalent to category 2$)$, typhoon $(119<$ wind $<156 \mathrm{~km} / \mathrm{h}$; equivalent to category 3$)$, very strong typhoon $(157 \mathrm{~km} / \mathrm{h}<$ wind $<193 \mathrm{~km} / \mathrm{h}$; equivalent to category $3 / 4)$ and violent typhoon (wind $>194 \mathrm{~km} / \mathrm{h}$; equivalent to category 5 ) 


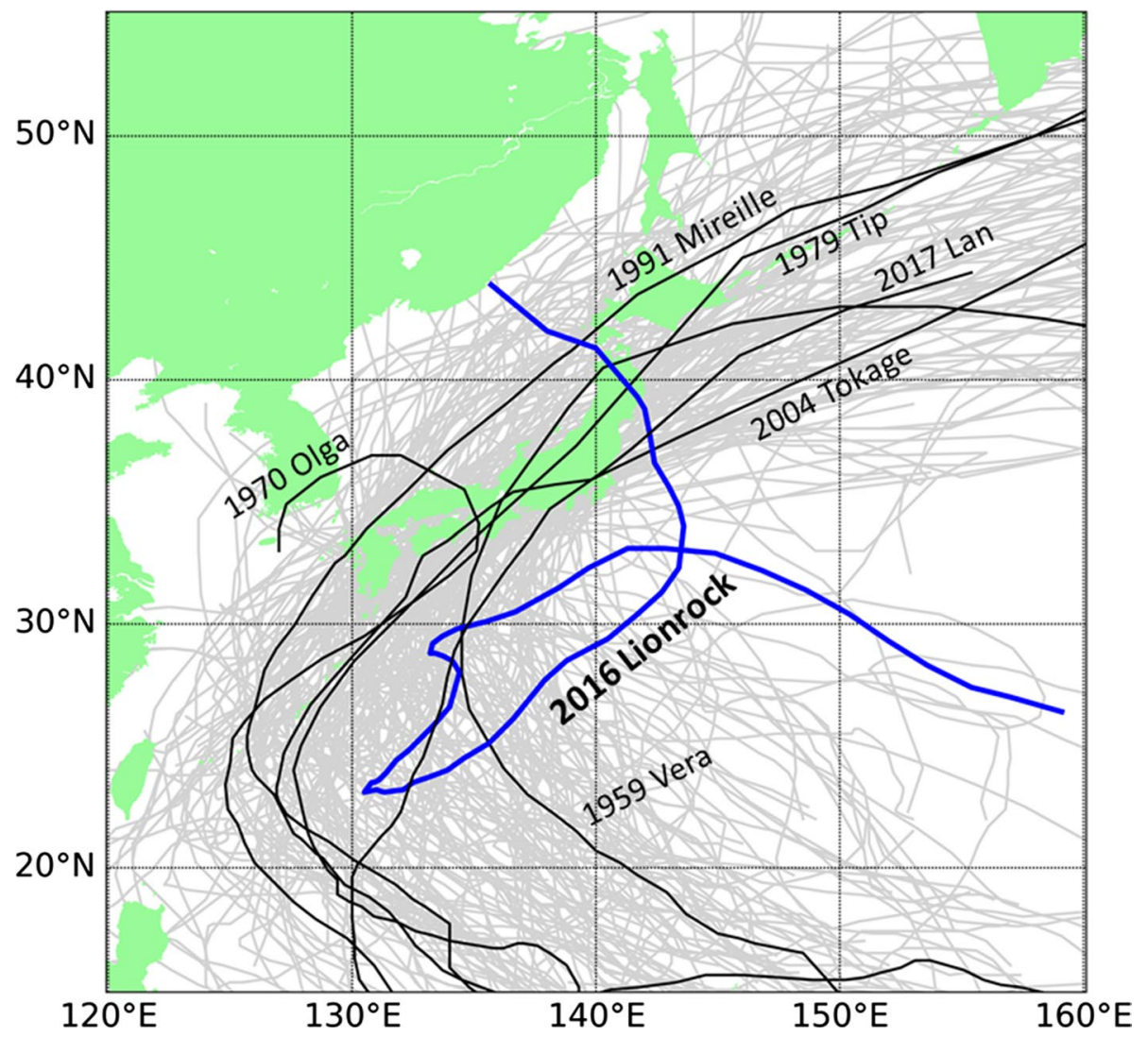

Fig. 1 The tracks of the tropical cyclones and typhoons affecting Japan since 1951, emphasizing seven major typhoons. Data are retrieved from the best track data of the Japan Meteorological Agency (2019)

and typhoons affecting Japan in the past half a century according to the Japan Meteorological Agency's (JMA) database.

A typhoon struck Japan in August 17-30, 2016, named as Typhoon Lionrock or Typhoon Dindo (the name in the Philippines assigned by PAGASA: Philippine Atmospheric, Geophysical and Astronomical Services Administration). It was the tenth storm named by the Japan Meteorological Agency (JMA) in 2016, hence known as typhoon number 1610 also. Typhoon Lionrock was among unique events as it started its landfall from north of Japan. The initial system was first detected $\sim 1000 \mathrm{~km}$ to the west of Chichijima, Japan (Fig. 2), on August 16, 2016, as a tropical depression by JMA. The United States Joint Typhoon Warning Center (JTWC) classified Lionrock as subtropical on August 17. The storm first moved northwestward until August 19; then traveled southwest and entered the Philippine Sea; and finally, returned to the north where it hit the eastern coast of Japan in August 29-30 (Fig. 2). Lionrock reached a maximum sustained wind speed of $135 \mathrm{mph}$ (equivalent to $\sim 220 \mathrm{~km} / \mathrm{h}$ ), a minimum central pressure of $\sim 940 \mathrm{hPa}$ and was classified as a category 4 hurricane in Saffir-Simpson Hurricane Wind Scale (SSHWS) and as a Typhoon in JMA scale. Lionrock made landfall in northeastern Japan followed by severe flooding resulting in a death toll of 22 based on the damage reports by Fire and Disaster 


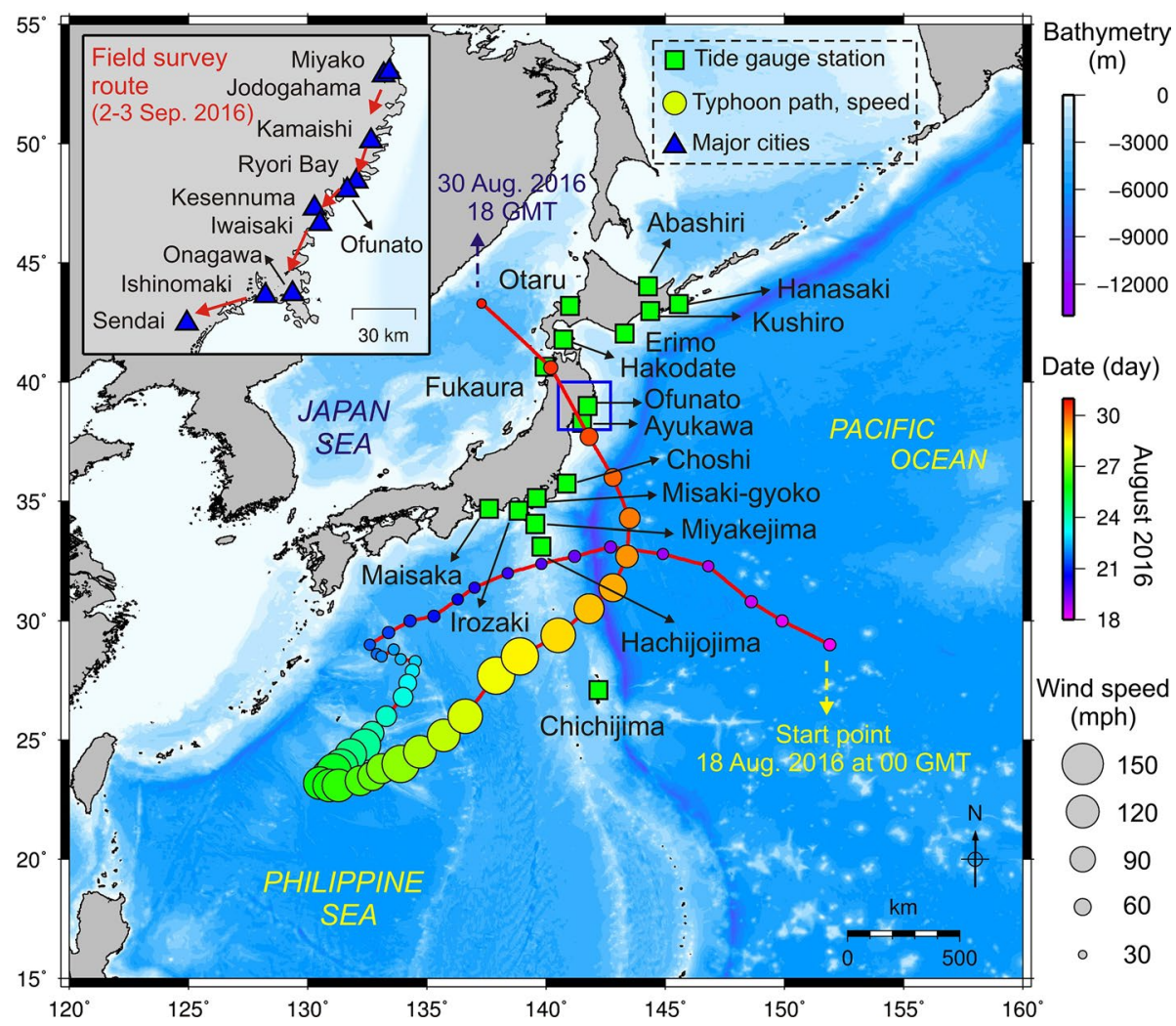

Fig. 2 Study area showing the location of tide gauge stations used in this study (green squares) and the speed, time and track of the typhoon (color circles). The size of each circle is proportional to the typhoon wind speed. The inset at the top-left corner illustrates the field survey route

Management Agency (FDMA 2017). Lionrock was the first Pacific storm making landfall in Tohoku region (north Japan) since 1951.

Here, we study the statistical properties of the surges generated by Typhoon Lionrock through analysis of observed tide gauge records and report the findings of our field survey of the areas affected by this typhoon. The field survey targeted the structural damage to coastal structures such as breakwaters and seawalls as well as measuring the shoreline inundation distance and height due to storm surges and waves. In addition, numerical modeling was performed to reconstruct the event.

\section{Data and methods}

\subsection{Tide gauge data analysis}

For tide gauge analysis, we used 16 tide gauge records along the coast of Japan provided by the JMA (see Fig. 2 for locations). The sampling interval of the records is $15 \mathrm{~s}$ except for the Ofunato station which is $1 \mathrm{~min}$, and the records are for the period from August 24, 2016 to September 3, 2016. The hourly tidal signals provided by JMA were used to 
de-tide the original records. Using the de-tided waveforms, the storm surge amplitudes were measured. Storm surge level was calculated by taking a 1-h moving average of the de-tided waveforms (e.g., Heidarzadeh et al. 2018, 2020a; Yalciner et al. 2014; Heidarzadeh and Satake 2013b). The period of storm surges is in the order of days justifying the application of a 1-h moving average. To calculate the duration of storm (SD) at each station, the average amplitude of the 10-day de-tided waveforms was calculated; then, storm duration was assumed to be the time interval that the amplitude is above this level. Waves are defined as short-period oscillations (i.e., periods $<20 \mathrm{~s}$ ) beyond the surge levels. As the sampling intervals of our tide gauge records are $15 \mathrm{~s}$, our data are not capable of appropriately recording wave oscillations although part of the wave oscillations can be seen in our result. Therefore, here we only calculate and report surge amplitude (SA) and surge duration (SD) in each station.

\subsection{Field surveys}

Field surveys were conducted to document the typhoon watermarks and structural damage to coastal structures and to measure the inundation distance and runup heights. The field work started in the morning of September 2, 2016, from Miyako and ended in the afternoon of September 3, 2016, in Sendai (see the survey path in Fig. 2). Inundation distance is the straight distance between the high-tide shoreline and the maximum extent of the seawater penetration inland (Heidarzadeh et al. 2018, 2020b). High-tide shoreline at the time of the survey can be approximated as the upper limit of the wet area of the coast which is usually easily visible. Runup height is the vertical difference between high-tide shoreline and that of the maximum extent of the seawater penetration point. As sea level changes due to astronomical tides, all sea level measurements were translated to Tokyo Peil (TP) which is the mean tide level at the Tokyo Bay. TP is widely used in Japan for tide-related research. A laser rangefinder of series Impulse by the Laser Technologies Inc. was used in the field to measure vertical and horizontal distances of inundation (http://www.lasertech. com/Impulse-Rangefinders.aspx). The group also was equipped with hand GPS devices of eTrex model by Garmin Inc. (http://sites.garmin.com/en-US/etrex/). Inundation limit was identified from the coastal debris. Watermarks and inundation limits of the typhoon were photographed, and their locations were determined using the GPS devices.

\subsection{Numerical simulations}

Regional Oceanic Modeling System, commonly known as ROMS (Shchepetkin and McWilliams 2005), was applied for simulations of the storm surge generated by Typhoon Lionrock. ROMS is free-surface and terrain-following coordinate ocean model, which applies mode-splitting method to solve governing equation (Shchepetkin and McWilliams 2005). We note that wind-generated waves are not considered in our numerical modeling because the sampling frequency of the observation data (i.e., $15 \mathrm{~s}$ ) does not allow resolving wind-generated waves which usually contain wave periods of 5-15 s. Our computational domain includes three nesting grids (Grid-1, Grid-2 and Grid-3; Fig. 3); the type of the nesting is a two-way nesting. The spatial resolutions of the Grid 1, Grid 2 and Grid 3 are $5000 \mathrm{~m}, 1000 \mathrm{~m}$ and $333 \mathrm{~m}$, respectively (Fig. 3; Table 2). The bathymetry data used for simulations are based on GEBCO-2014 (The General Bathymetric Chart of the Oceans) (Weatherall et al. 2015) for Grid 1 and the Cabinet Office of the Japan government for Grid 2 and Grid 3. The original resolution of the GEBCO-2014 data is 30 arc-sec (approximately 


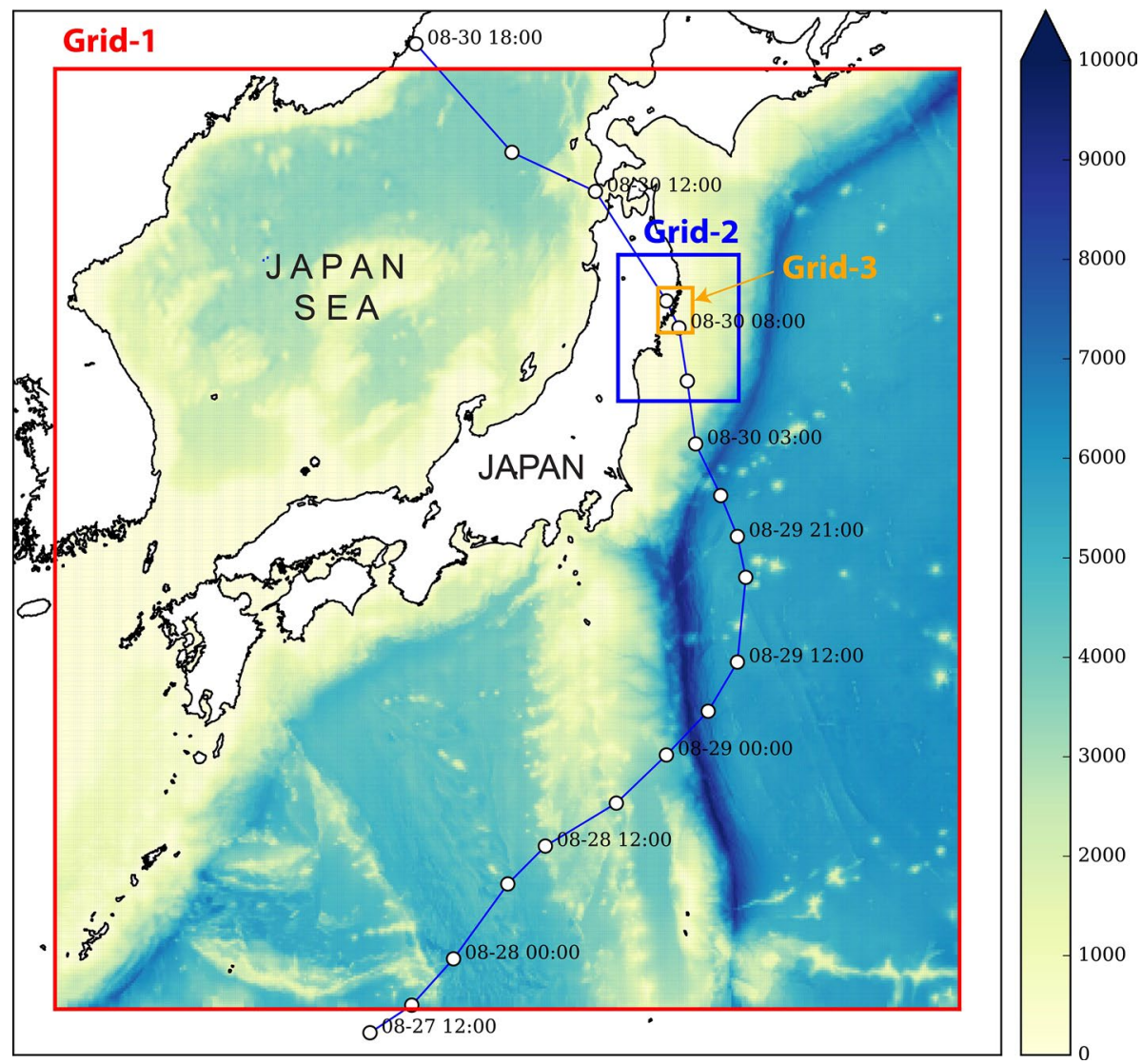

Fig. 3 Computational domain including three nested grids (red, blue and orange domains) used for numerical modeling of the 2016 Typhoon Lionrock. The white solid circles show the track of the typhoon

$925 \mathrm{~m}$ ), and those of the Cabinet Office of the Japan Government are $1350 \mathrm{~m}$ for Grid 2 and $450 \mathrm{~m}$ for Grid 3. In order to damp numerical oscillation due to two-way nesting process, bathymetry at the borders of parent and child grids was designated to be the same and horizontal eddy viscosity was set to be $10^{3}\left(\mathrm{~m}^{2} / \mathrm{s}\right)$. Other simulation parameters are listed in Table 2. For external forcing, the Meso-Scale Model Grid Point Values (MSM-GPV) provided by the JMA were used for our ROMS model in this study. Hourly 10-m eastward/ northward wind field and sea level pressure were converted to the readable format for our ROMS model. The reproducibility of MSM-GPV was checked by comparing observation data. We chose five points close to the observation sites, and the 10-m wind and sea level pressure were extracted. These five points are marked as $(x, y-1),(x-1, y),(x, y),(x+1$, $y)$ and $(x, y+1)$ in Figs. 4 and 5 which are the neighboring grid points to the observation points. Then, height correction of $10-\mathrm{m}$ wind by $1 / 7$ power law was done at each site, and the comparison was conducted. We designated the six observation stations of Miyako, Ofunato, Ishinomaki, Sendai, Onahama and Fukushima for this comparison. Figures 4 and 5 show the results of such comparison. It can be seen from Figs. 4 and 5 that the velocity and pressure values at neighboring grid points show consistent behavior, and they match the observations. This check confirms that our input velocity and pressure fields are valid. 
Table 2 Parameters used for numerical simulations of Typhoon Lionrock in this study

\begin{tabular}{|c|c|c|c|}
\hline Time period of simulation & \multicolumn{3}{|c|}{ Start: $2016 / 08 / 25$ at $12: 00$ (UTC) } \\
\hline & \multicolumn{3}{|c|}{ End: $2016 / 08 / 31$ at $18: 00$ (UTC) } \\
\hline Ramping time (h): & \multicolumn{3}{|l|}{12} \\
\hline Spatial resolution $(\mathrm{m})$ & \multicolumn{3}{|c|}{ Grid 1: 5000} \\
\hline & \multicolumn{3}{|c|}{ Grid 2: 1000} \\
\hline & \multicolumn{3}{|c|}{ Grid 3: 333} \\
\hline \multirow[t]{3}{*}{ Number of grid points } & \multicolumn{3}{|c|}{ Grid 1: $435 \times 360$} \\
\hline & \multicolumn{3}{|c|}{ Grid 2: $290 \times 280$} \\
\hline & \multicolumn{3}{|c|}{ Grid 3: $415 \times 430$} \\
\hline Vertical layer & Three 1 & & \\
\hline \multirow[t]{4}{*}{ Time step (s) } & & Baroclinic & Barotropic \\
\hline & Grid 1: & 45 & 4.5 \\
\hline & Grid 2: & 15 & 1.5 \\
\hline & Grid 3: & 3 & 0.333 \\
\hline \multirow[t]{2}{*}{ Source of bathymetry } & \multicolumn{3}{|c|}{ Grid 1: GEBCO-2014 } \\
\hline & \multicolumn{3}{|c|}{ Grid 2 and Grid 3: Cabinet office of the Japanese government } \\
\hline Minimum water depth (m) & \multicolumn{3}{|c|}{1} \\
\hline Horizontal viscosity $\left(\mathrm{m}^{2} / \mathrm{s}\right)$ & \multicolumn{3}{|l|}{1000} \\
\hline
\end{tabular}

\section{Analysis of typhoon surges based on tide gauge data}

Figures 6 and 7 show the results of waveform analyses including the original records (Fig. 6a, black), the tide (Fig. 6a, red), the de-tided waveforms (Fig. 6b) and the storm surge (pink lines in Fig. $6 \mathrm{~b}$ and the shaded areas in Fig. $6 \mathrm{c}$ ). It can be seen that the surge waveforms differ from one station to another, which can be attributed to the changes in bathymetry, wind direction and speed as well as pressure at various locations. Storm surge amplitudes are in the range of $15-55 \mathrm{~cm}$ with the peak surge occurring at Ofunato station. The average and standard deviation of the surge amplitudes are 32 and $12 \mathrm{~cm}$, respectively, indicating the values are close to each other (Fig. 7a). At three stations of Abashiri, Otaru and Fukaura, the noise levels are higher than the surge signals and thus the surge characteristics are not reported. The typhoon track was close to Ayukawa and Ofunato (Fig. 7); however, the largest surge amplitude in Ofunato cannot be necessarily attributed to the typhoon track because in other stations, located far from the track such as Erimo and Choshi, also the surge amplitudes are large. The surge duration appears to be approximately uniform with an average value of 2.5 days (Figs. 6c, 7b). Because the maximum surge amplitude was $55 \mathrm{~cm}$, the surges generated by Lionrock were moderate and thus we did not expect significant coastal damage. This hypothesis was later confirmed during our field surveys of the affected coastal areas. 

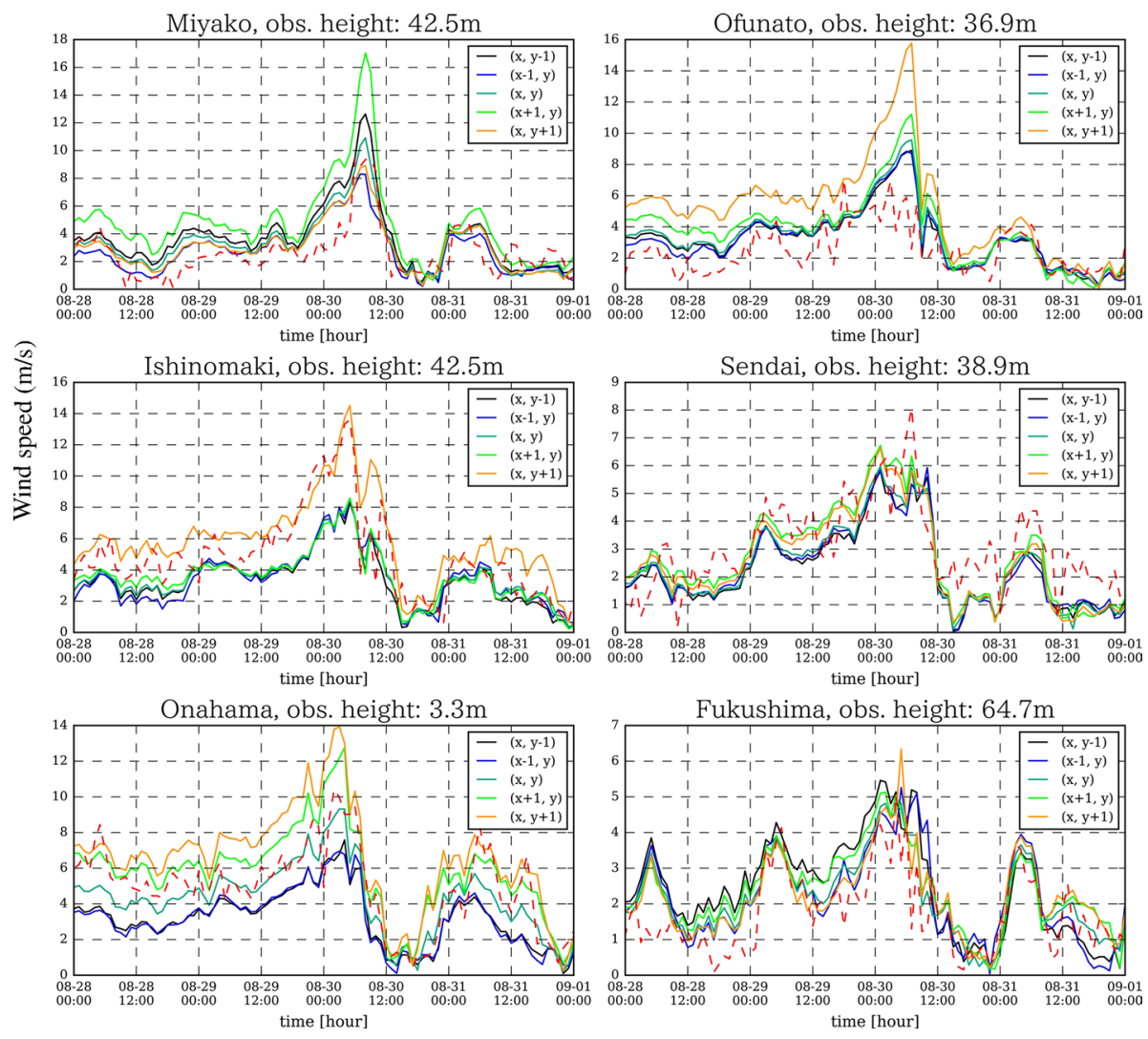

Fig. 4 Comparison of 10-m wind speed $(\mathrm{m} / \mathrm{s})$ at six observation points for the 2016 Typhoon Lionrock. The dashed red line is for the observations, and other colors are the values from MSM-GPV

\section{Results of field survey}

\subsection{Watermarks}

The most prominent watermark observed during the field surveys was the accumulation of wooden debris along the coastlines (Fig. 8a, c). In cases where vegetation was available at the coast, they were damaged by the surge/wave actions (Fig. 8d). A wave-associated damage was observed in Ryori Bay where the door of a building was damaged (Fig. 8b). Since the window glasses of the same door were undamaged, it may indicate that the typhoongenerated winds were unable to damage the windows, whereas the waves broke the door.

\subsection{Runup heights and inundation distances}

As expected from tide gauge data analysis, our field survey revealed that the coastal damage was moderate and the surveyed runup heights and distances were relatively small. Therefore, we were unable to establish wave runup points at some of the surveyed locations. We 

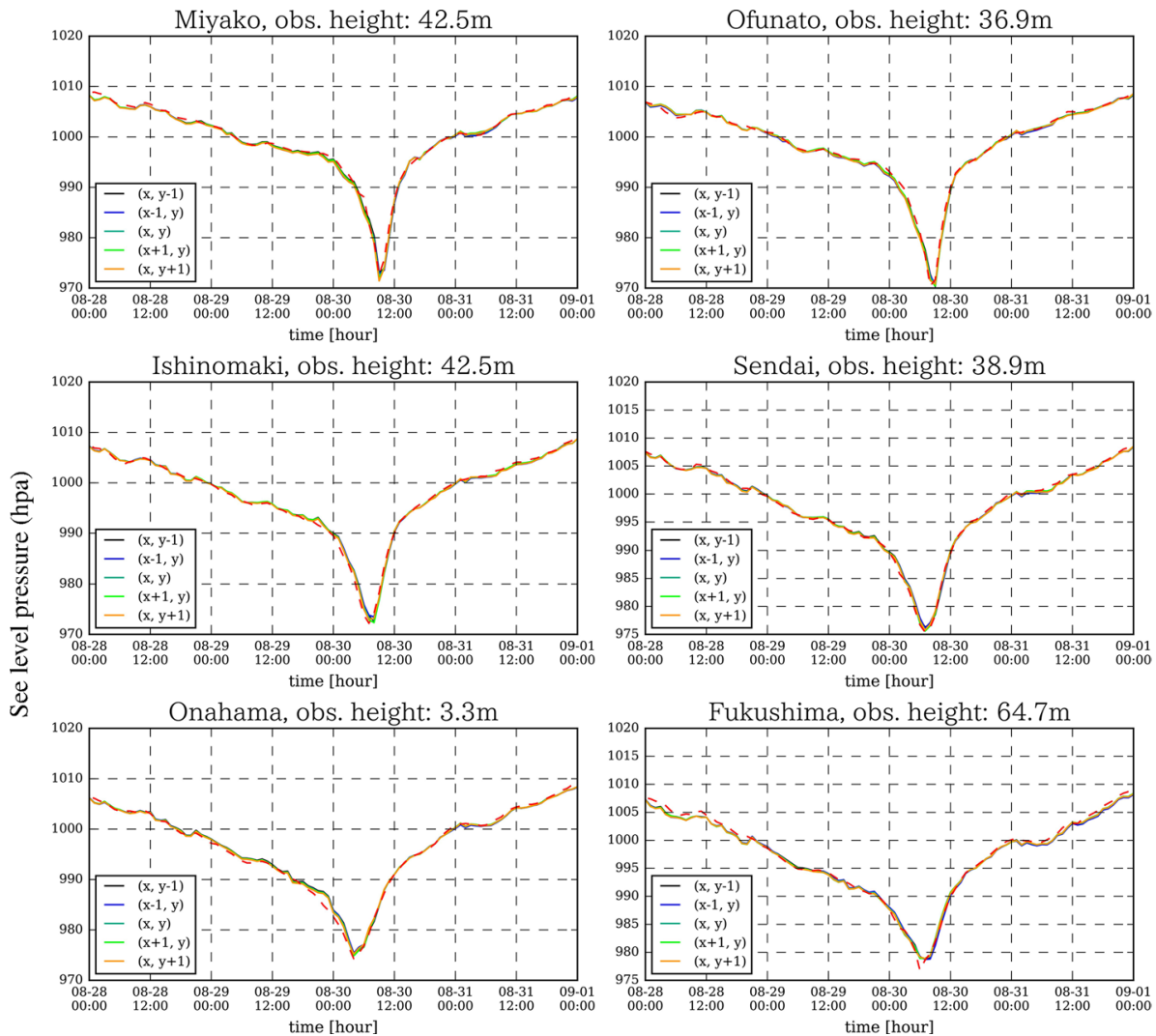

Fig. 5 Comparison of sea level pressure $(\mathrm{hPa})$ at six observation points for the 2016 Typhoon Lionrock. The red line is for the observations, and other colors are the values from MSM-GPV

measured runup heights and inundation distances at three locations along the northeastern coast of Japan (Fig. 9). The runup heights ranged from 1.7 to $4.3 \mathrm{~m}$, whereas inundation distances varied in the range of 16-56 m (Fig. 9). In all three locations, the coastal debris brought to the shore by the storm formed a clear line helping to establish the inundation limits (Fig. 9).

\subsection{River flooding and sedimentation}

The heavy landfall caused by the Typhoon Lionrock generated floods in many rivers along the northeastern coast of Japan. We surveyed the city of Miyako which was flooded and was covered with heavy mud after the typhoon (Fig. 10a, b). Figure 10 shows the city is being cleared up of the mud using construction machines and manpower. The construction site of a river bridge also was visited which was covered by many wooden debris (Fig. 10c). According to site engineers, the flood height was $\sim 5.5 \mathrm{~m}$ above the river's normal level causing inundation of the nearby road (Fig. 10d). 
(a) Original records (black) and tides (red)

(b) De-tided waveforms

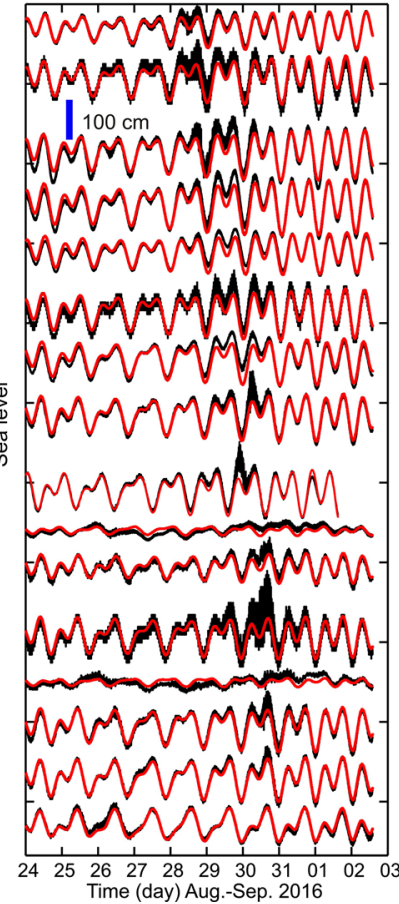

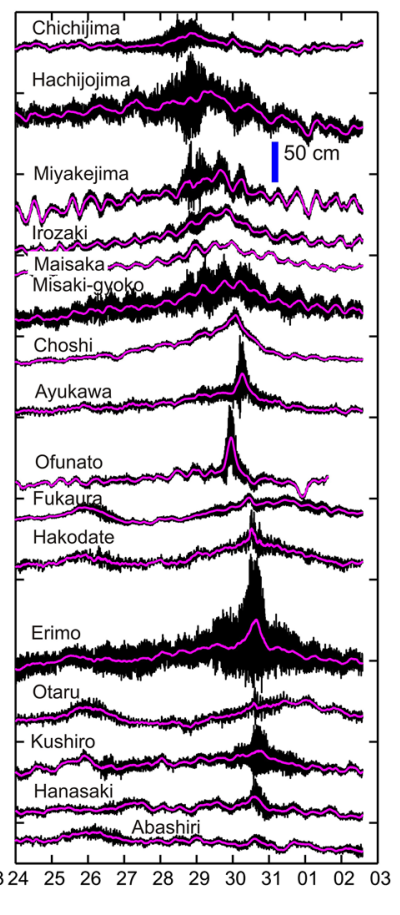

(C) Surge amplitudes and durations

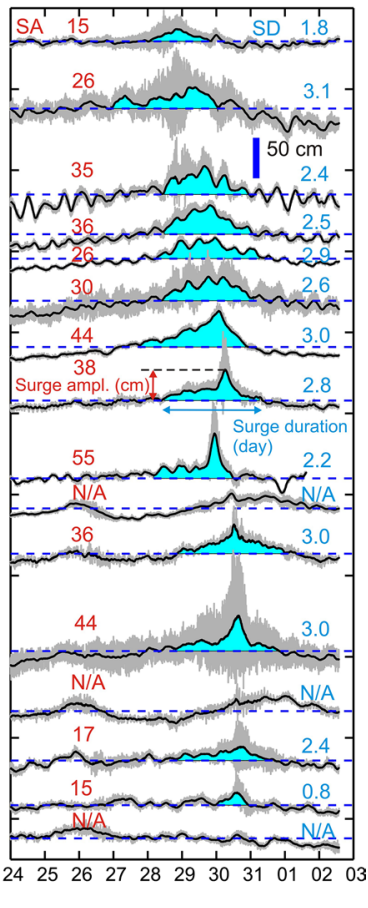

Fig. 6 Original (a, black records) and de-tided (b) tide gauge records. The tide prediction is given in red in panel "a," which is based on the data from JMA. The pink curves are 1-h averaged waveforms which represent the surge levels at various stations. c Surge amplitudes (SA; red values) and surge durations (SD; blue values). N/A stands for "not applicable"

(a) Surge amplitudes (tide gauge data) Average value $=32 \mathrm{~cm}$ Standard deviation $=12 \mathrm{~cm}$

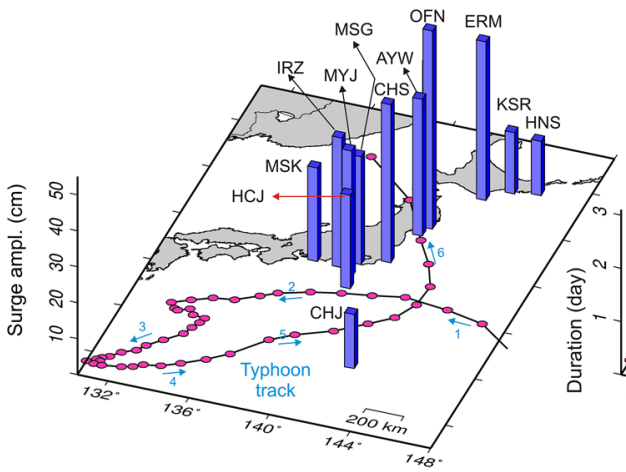

(b) Duration of surge (tide gauge data) Average value $=2.5$ days Standard deviation $=0.6$ days

Fig. 7 a Maximum tide gauge surge amplitudes of the Typhoon Lionrock at various locations. The numbers 1-6 show the temporal evolution of the typhoon path. b Duration of storm surge at various locations. Abbreviations for location names are: $C H J$ Chichijima, $M S K$ Maisaka, $C H S$ Choshi, AYW Ayukawa, OFN Ofunato, HCJ Hachijo-jima, HNS Hanasaki, KSR Kushiro, IRZ Irozaki, MYJ Miyakejima, ERM Erimo, $M S G$ Misaki Gyoko, HKD Hakodate 

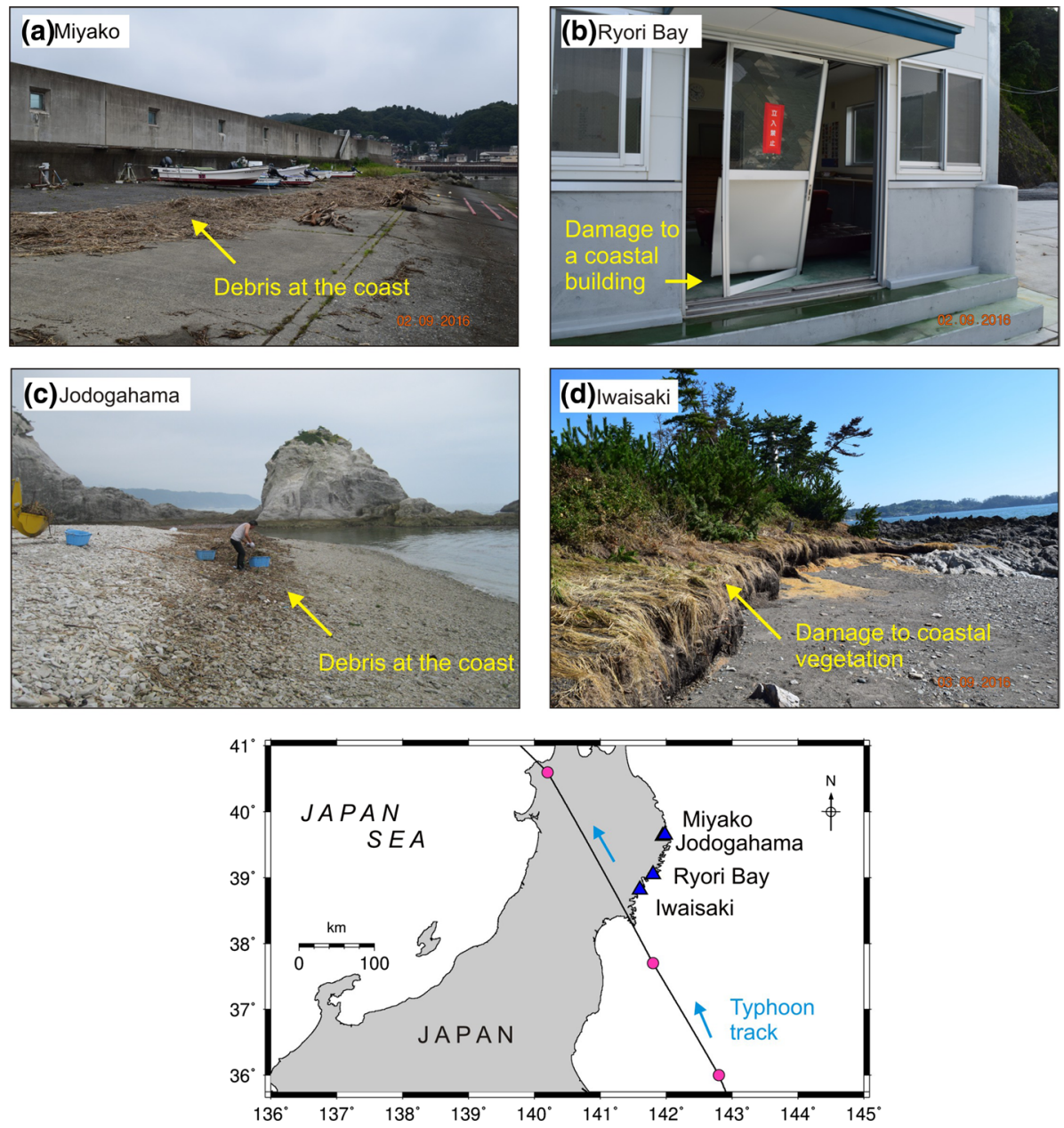

Fig. 8 Watermarks of the Typhoon Lionrock at different locations observed in the field survey. A worker is seen in panel "c" cleaning up the debris at the coast. Approximate locations of the photographs are: $39.6467^{\circ} \mathrm{N}$ and $141.9712^{\circ} \mathrm{E}$ for panel "a," $39.0563^{\circ} \mathrm{N}$ and $141.8136^{\circ} \mathrm{E}$ for panel "b," $39.6523^{\circ} \mathrm{N}$ and $141.9787^{\circ} \mathrm{E}$ for panel "c" and $38.8276^{\circ} \mathrm{N}$ and $141.6032^{\circ} \mathrm{E}$ for panel "d"

\subsection{Structural damage}

Examples of structural damages to coastal structures are shown in Fig. 11. In Ryori Bay, a few breakwater concrete blocks were overturned (Fig. 11a, b). A site engineer advised that the breakwater was under rehabilitation and tetrapod armour units were scheduled to be placed in front of the breakwater. The damage was sustained mostly in the part of the breakwater which was not protected with tetrapod units (Fig. 11a). In Ofunato, a gap of approximately $1 \mathrm{~m}$ was produced between breakwater concrete units (Fig. 11d). The photograph of the same breakwater before the typhoon reveals that the units were joined together before the event (Fig. 11c). 

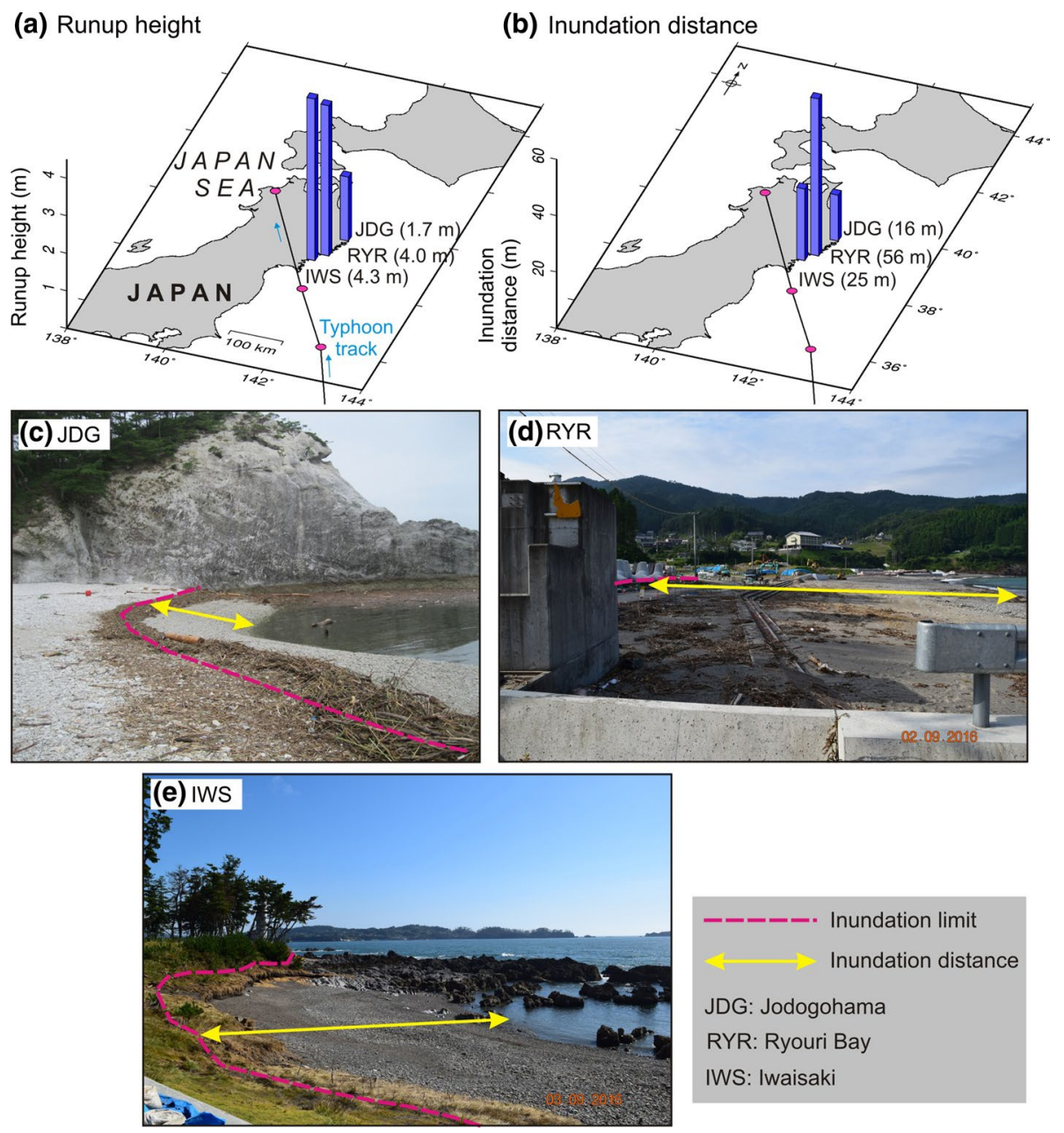

JDG: Jodogohama

RYR: Ryouri Bay

IWS: Iwaisaki

Fig. 9 Runup heights (a) and inundation distances (b) at three locations of Jodogohama (JDG) (c), Ryouri Bay (RYR) (d) and Iwaisaki (IWS) (e) due to 2016 Typhoon Lionrock. Approximate locations of the photographs are: $39.6523^{\circ} \mathrm{N}$ and $141.9787^{\circ} \mathrm{E}$ for panel "c," $39.0563^{\circ} \mathrm{N}$ and $141.8136^{\circ} \mathrm{E}$ for panel "d," $38.8276^{\circ} \mathrm{N}$ and $141.6032^{\circ} \mathrm{E}$ for panel "e"

\section{Results of numerical simulations}

Snapshots of storm surge modeling of the 2016 Typhoon Lionrock is shown in Fig. 12, while Fig. 13 compares observed and simulated waveforms on tide gauges. In general, our three-level nested grid system and the input wind and pressure fields provided a numerical model for this event which resulted in a good agreement between observation and simulations (Fig. 13). Most stations show very good match between observation and simulations. In Ofunato, the simulations underestimate the observations, approximately $7 \mathrm{~cm}$ which can be considered negligible. It is challenging to specifically identify the reason(s) for such underestimation; candidate factors could be attributed to wave setup, which exist in the 

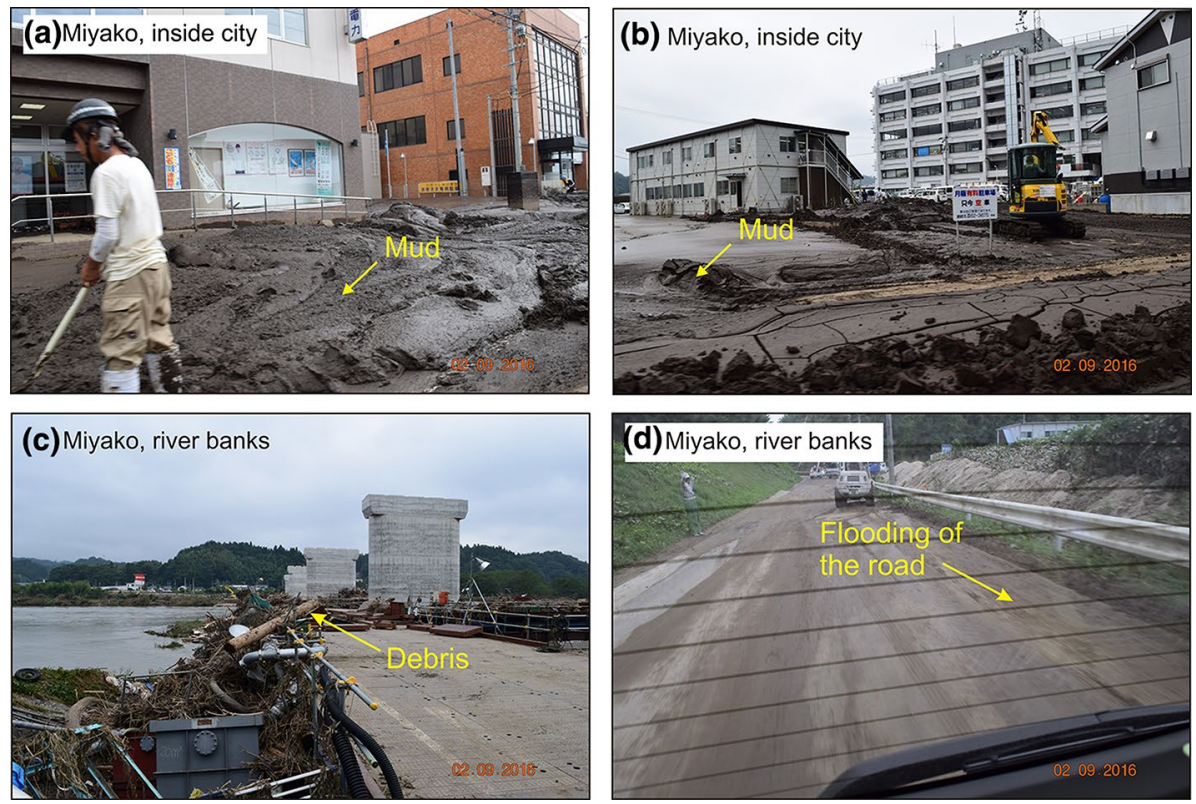

Fig. 10 Flooding of the Miyako city (a, b) and the river banks (c, d) due to the 2016 Typhoon Lionrock. Approximate locations of the photographs are: $39.6431^{\circ} \mathrm{N}$ and $141.9597^{\circ} \mathrm{E}$ for panels "a" and "b" and $39.6305^{\circ} \mathrm{N}$ and $141.9245^{\circ} \mathrm{E}$ for panels "c" and "d"

reality but are not considered in our simulations, or to some errors in the input velocity and pressure fields. Overall, our numerical model can satisfactorily reproduce the 2016 Typhoon Lionrock. This validated numerical model can be used in the future for typhoonhazard studies along the coast of northeastern Japan.

\section{Discussions}

Table 3 compares category 4 Lionrock with a few other category 4 typhoons that struck Japan in the past. Lionrock's runup is smaller than that of other category 4 typhoons, but its death toll is more than that of the 2017 Typhoon Lan and 2018 Typhoon Jebi whose runups were approximately double or more. Two reasons could be considered for the relatively smaller runup heights of Lionrock: (1) typhoons are classified based on their maximum sustained wind speed, while coastal surge mainly depends on the fluctuations of the central pressure of a typhoon system; wind is mostly responsible for wave actions along the coast, and (2) although Lionrock was a category 4 typhoon, it was weakened to category 2 at the time of landfall in east Japan. Data of intensity and death toll for a few typhoons in the past in Table 3 reveal that a linear relationship between the intensity of a typhoon and its death toll or coastal surge height is not possible. This was evidenced in other typhoons and hurricanes worldwide too (Fritz et al. 2007). The reason for this can be attributed to various mechanisms that contribute to damage/death during a typhoon (Heidarzadeh et al. 2018). For example, most damage/death during the 2016 Typhoon Lionrock was due to inland flooding, while the wind-blown debris 

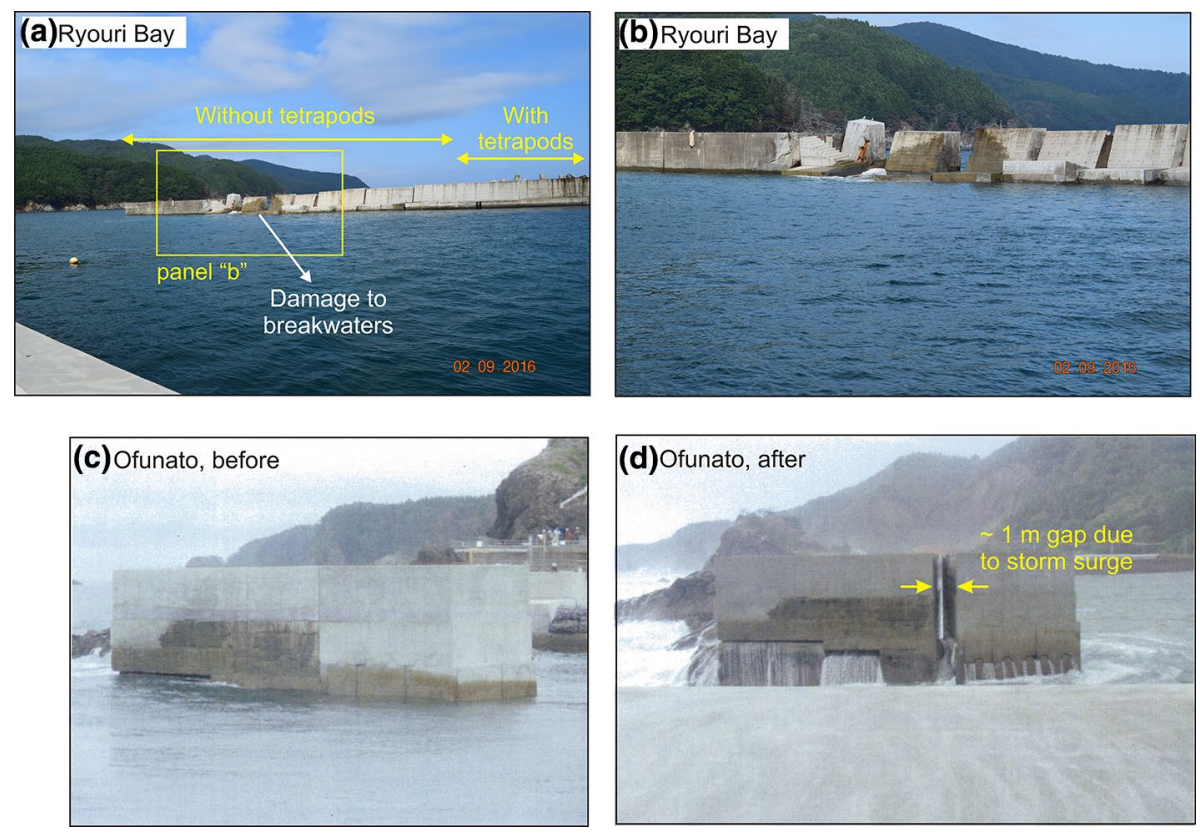

Fig. 11 Structural damage to breakwaters in Ryouri Bay (a and b) and Ofunato (c and d). Photographs shown in "c" and "d" are provided by Kamaishi port authorities. Approximate locations of the photographs are: $39.0563^{\circ} \mathrm{N}$ and $141.8136^{\circ} \mathrm{E}$ for panels "a" and "b" and $39.0623^{\circ} \mathrm{N}$ and $141.7305^{\circ} \mathrm{E}$ for panels "c" and "d." The dates for panels "c" and "d" are August 26, 2018 (before typhoon), and August 31, 2016 (after typhoon), respectively

and falling debris were responsible for most of the damage/death of the 1991 Typhoon Mireille. And mudslides were the dominating features of the 2004 Typhoon Tokage. In other words, various primary and secondary damaging effects are associated with typhoons such as flooding, surges, waves, strong winds (primary hazards), landslides, coastal erosions, debris flows, mud flows and wind-blown debris (secondary hazards) (Fig. 14). Therefore, depending on the meteorological and geomorphological conditions of a typhoon-stricken area, the dominating damage mechanism and the interactions between various mechanisms will be different. In fact, the various primary and secondary effects caused by a typhoon make it more complicated in terms of hazard mitigation from a tsunami event whose damage/death is dominated by inundation and debris flows. From typhoon resilience point of view, it is critical to understand these various primary and secondary damage/death mechanisms and to study the potential for their occurrences and interactions.

\section{Conclusions}

The characteristics and damaging effects of the August 2016 Typhoon Lionrock were studied through analysis of tide gauge records, field surveys and numerical simulations. Main findings are: 

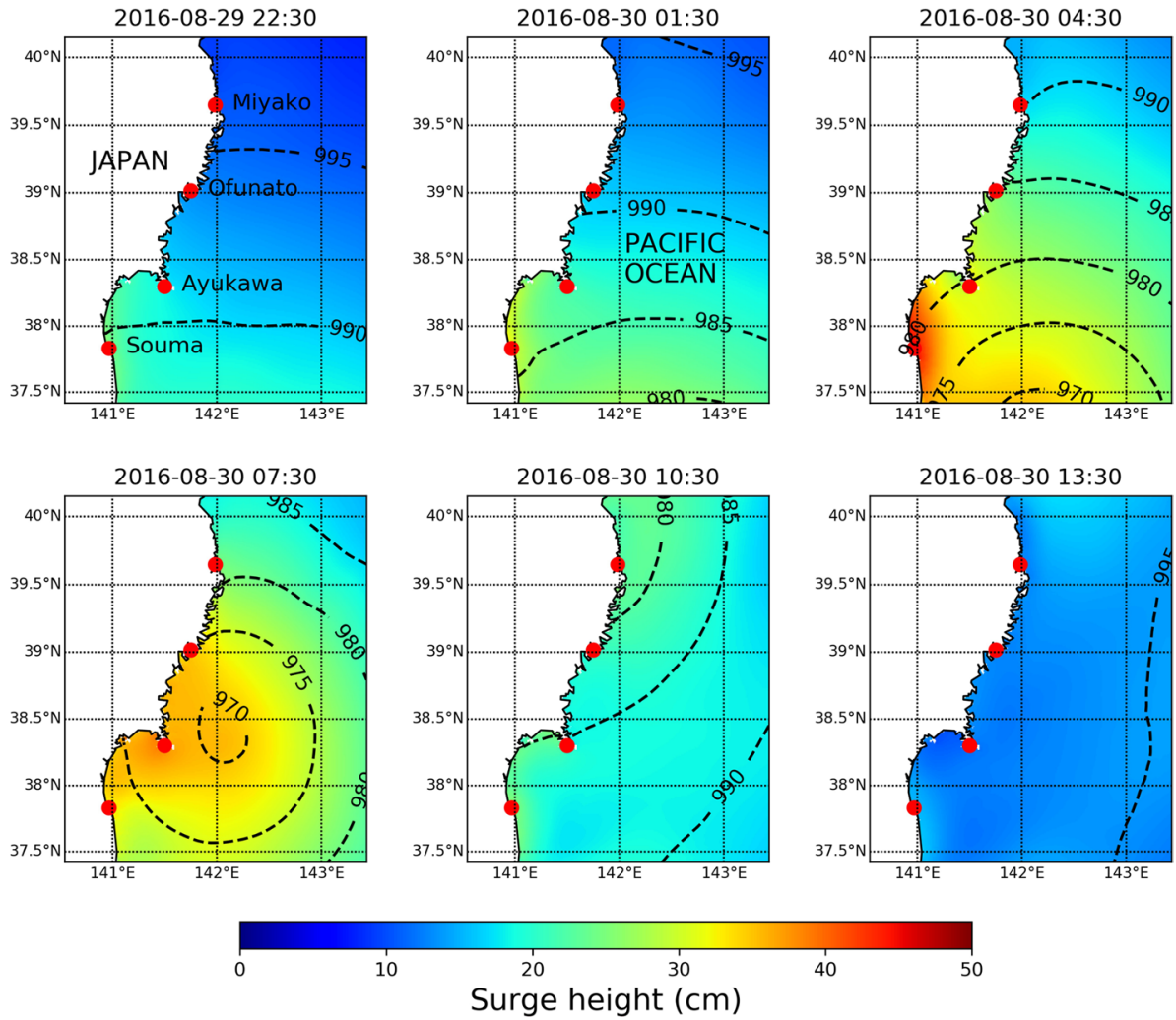

Fig. 12 Snapshots of 2016 Typhoon Lionrock surge propagation in the northeastern Japan based on the numerical simulations of this study. Dashed contours give the air pressure field

- Among 16 tide gauge data analyzed in this study from western and northern coasts of Japan, the surge amplitude and surge duration were in the ranges of $15-55 \mathrm{~cm}$ and 0.8-3.1 days, respectively. Largest surge amplitude occurred in Ofunato. These relatively moderate values for surge amplitude look disproportionate to the intensity of the Lionrock as a category 4 typhoon.

- Field surveys of the typhoon-stricken areas confirmed that the damage to coastal structures and communities was moderate although it caused severe flooding inland. The maximum coastal wave runup was measured in Iwaisaki as $4.3 \mathrm{~m}$, which was smaller than that generated by other category 4 typhoons in Japan.

- Different damage modes were observed: river flooding and associated intense sedimentation and mud flows as well as surge/wave impacts on the coastal areas.

- Our numerical model was able to satisfactorily reproduce the storm surge of Lionrock. This validated numerical model can be used in the future for typhoon-hazard studies along the coast of northeastern Japan.

- Although the runup height of Lionrock was smaller than that of other category 4 typhoons, its death toll was more than that of typhoons Jebi and Lan with larger runup heights. We attribute this to various primary (e.g., flooding, surges, waves, strong winds) and secondary (e.g., landslides, coastal erosions, debris flows, mud 

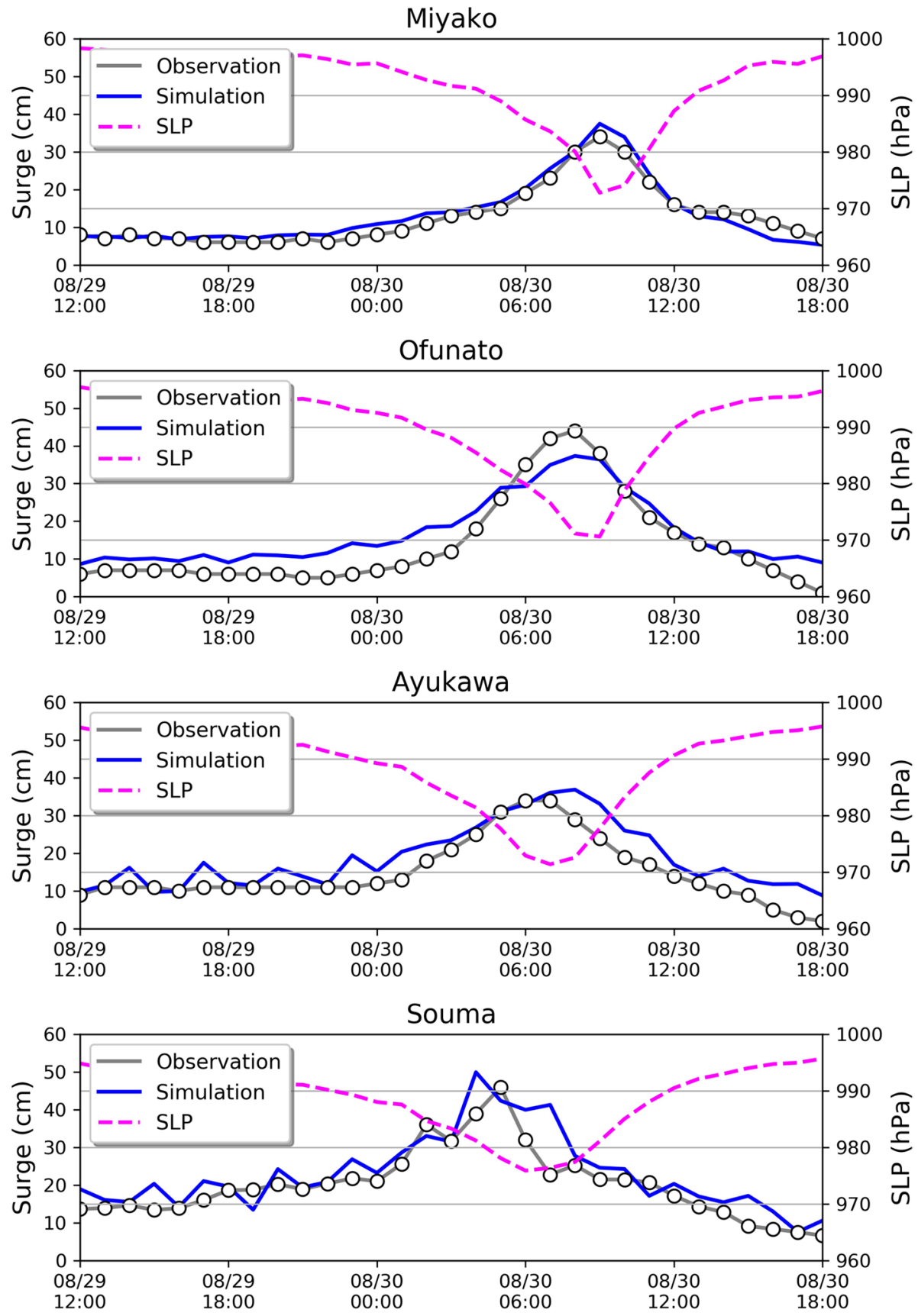

Fig. 13 Comparison of observed (gray) and simulated (blue) surge during the 2016 Typhoon Lionrock in some of the tide gauge stations. Pink lines are the fluctuations of the sea-level pressure 
Table 3 Maximum surge/wave heights and level of damage made by a number of category 4 typhoons in Japan

\begin{tabular}{llllll}
\hline $\begin{array}{l}\text { Typhoon name } \\
\text { (year) }\end{array}$ & $\begin{array}{l}\text { JMA } \\
\text { intensity }\end{array}$ & $\begin{array}{l}\text { Maxi- } \\
\text { mum } \\
\text { runup }\end{array}$ & $\begin{array}{l}\text { Death } \\
\text { toll }\end{array}$ & Main cause of damage & References \\
& & &
\end{tabular}

(m)

\begin{tabular}{|c|c|c|c|c|c|}
\hline Jebi (2018) & Typhoon & 8.0 & 13 & Wind-blown debris & Le et al. (2018) \\
\hline Lan (2017) & Typhoon & $>6.7 \mathrm{~m}$ & 8 & $\begin{array}{l}\text { Inland flooding; land- } \\
\text { slides; surge/waves }\end{array}$ & $\begin{array}{l}\text { Islam et al. (2018); https:// } \\
\text { www.cyclocane.com/lan- } \\
\text { storm-tracker/ }\end{array}$ \\
\hline $\begin{array}{l}\text { Lionrock } \\
\quad(2016)\end{array}$ & Typhoon & 4.3 & 22 & $\begin{array}{l}\text { Inland flooding; mud } \\
\text { flows; debris flows }\end{array}$ & Our field works; media reports \\
\hline Tokage (2004) & Typhoon & 12 & 69 & $\begin{array}{l}\text { Inland flooding; mud- } \\
\text { slides }\end{array}$ & $\begin{array}{l}\text { Kim et al. (2007), Esteban and } \\
\text { Shibayama (2008) }\end{array}$ \\
\hline $\begin{array}{r}\text { Mireille } \\
(1991)\end{array}$ & Typhoon & 13.7 & 64 & $\begin{array}{l}\text { Wind-blown debris; } \\
\text { falling debris; inland } \\
\text { flooding; landslides }\end{array}$ & Takemi et al. (2016) \\
\hline
\end{tabular}

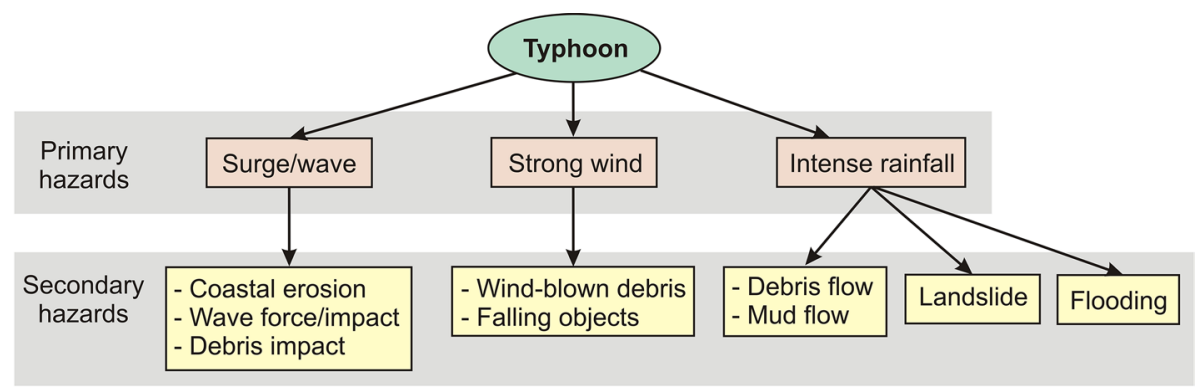

Fig. 14 Various primary and secondary damaging effects caused by typhoons based on the data from recent typhoons in Japan

flows, wind-blown debris) mechanisms that contribute to damage/death during a typhoon.

Acknowledgements The tide gauge records and the astronomical tidal levels are provided by the Japan Meteorological Agency (JMA). We also used JMA best track database for the tropical storms/typhoons affecting Japan since 1951. The GMT software was employed for drafting some of the figures (Wessel and Smith 1998). We acknowledge Kamaishi port authorities for providing some storm damage photographs shown in one of our figures. We are sincerely grateful to Professor James Goff (the Editor-in-Chief) and two anonymous reviewers for their constructive review comments which greatly helped to improve this article. MH was supported by the Brunel University London through the Brunel Research Initiative and Enterprise Fund 2017/18 (BUL BRIEF). HT was supported by grants to Tokyo Institute of Technology from the JSPS KAKENHI (No. 16KK0121).

\section{Compliance with ethical standards}

Conflict of interest The authors declare that they have no competing interests. The data and material used in this research are partly available in the body of the article; other data/material is also available to public and 
will be provided through writing to the corresponding author.

Open Access This article is licensed under a Creative Commons Attribution 4.0 International License, which permits use, sharing, adaptation, distribution and reproduction in any medium or format, as long as you give appropriate credit to the original author(s) and the source, provide a link to the Creative Commons licence, and indicate if changes were made. The images or other third party material in this article are included in the article's Creative Commons licence, unless indicated otherwise in a credit line to the material. If material is not included in the article's Creative Commons licence and your intended use is not permitted by statutory regulation or exceeds the permitted use, you will need to obtain permission directly from the copyright holder. To view a copy of this licence, visit http://creativecommons.org/licenses/by/4.0/.

\section{References}

Cerveny RS, Lawrimore J, Edwards R, Landsea C (2007) Extreme weather records: compilation, adjudication, and publication. Bul Am Meteorol 88(6):853-860

Chock GYK (2016) Design for tsunami loads and effects in the ASCE 7-16 standard. J Struct Eng 142(11):04016093

Esteban M, Shibayama T (2008) Computational estimation of caisson sliding and tilting of Susami West breakwater due to Typhoon Tokage. In: Proceedings of civil engineering in the ocean, vol 24. Japan Society of Civil Engineers, pp 531-536

Fire and Disaster Management Agency (2017) Damages caused by Typhoon 1610 (report no. 43). https:// www.fdma.go.jp/disaster/info/assets/post816.pdf

Fritz HM, Blount C, Sokoloski R, Singleton J, Fuggle A, McAdoo BG, Moore A, Grass C, Tate B (2007) Hurricane Katrina storm surge distribution and field observations on the Mississippi Barrier Islands. Estuar Coast Shelf Sci 74(1):12-20

Fritz HM, Blount CD, Thwin S, Thu MK, Chan N (2009) Cyclone Nargis storm surge in Myanmar. Nat Geosci 2(7):448-449

Fritz HM, Petroff CM, Catalán PA, Cienfuegos R, Winckler P, Kalligeris N, Weiss R, Barrientos SE, Meneses G, Valderas-Bermejo C, Ebeling C (2011) Field survey of the 27 February 2010 Chile tsunami. Pure Appl Geophys 168(11):1989-2010

Goda Y, Hashimoto H (1983) Storm surge defense works and related researches in Japan. In: Wind and seismic effects, proceedings of the fourteenth joint UJNR panel conference of the US-Japan cooperative program in natural resources, May 17-20, 1982, Washington DC

Hamuro M, Kawata Y, Matsuda S, Matusno T, Nakamura N, Pak T, Takeda T, Yanai M (1969) Precipitation bands of Typhoon Vera in 1959 (Part I). J Meteorol Soc Jpn Ser II 47(4):298-309

Heidarzadeh M, Satake K (2013a) Waveform and spectral analyses of the 2011 Japan tsunami records on tide gauge and DART stations across the Pacific Ocean. Pure Appl Geophys 170(6-8):1275-1293

Heidarzadeh M, Satake K (2013b) The 21 May 2003 tsunami in the Western Mediterranean Sea: statistical and wavelet analyses. Pure Appl Geophys 170(9):1449-1462

Heidarzadeh M, Teeuw R, Day S, Solana C (2018) Storm wave runups and sea level variations for the September 2017 Hurricane Maria along the coast of Dominica, eastern Caribbean Sea: evidence from field surveys and sea level data analysis. Coast Eng J 60(3):371-384

Heidarzadeh M, Ishibe T, Sandanbata O, Muhari A, Wijanarto AB (2020a) Numerical modeling of the subaerial landslide source of the 22 December 2018 Anak Krakatoa volcanic tsunami, Indonesia. Ocean Eng. https://doi.org/10.1016/j.oceaneng.2019.106733

Heidarzadeh M, Rabinovich AB, Kusumoto S, Rajendran CP (2020b) Field surveys and numerical modeling of the 26 December 2004 Indian Ocean tsunami in the area of Mumbai, west coast of India. Geophys J Int. https://doi.org/10.1093/gji/ggaa277

Hoshino S, Esteban M, Mikami T, Takagi H, Shibayama T (2015) Estimation of increase in storm surge damage due to climate change and sea level rise in the Greater Tokyo area. Nat Hazards 80(1):539-565

Irish JL, Lynett PJ, Weiss R, Smallegan SM, Cheng W (2013) Buried relic seawall mitigates Hurricane Sandy's impacts. Coast Eng 80:79-82

Islam MD, Takagi H, Anh LT, Takahashi A, Bowei K (2018) 2017 typhoon Lan reconnaissance field survey in coasts of Kanto Region, Japan. J Jpn Soc Civ Eng Ser B3 Ocean Eng 74(2):I_593-I_598. https:// www.jstage.jst.go.jp/article/jscejoe/74/2/74_I_593/_pdf/-char/ja 
Kim TM, Yasuda T, Mase H, Takayama T (2007) Computational reproduction of caisson sliding failure due to Typhoon Tokage. Proc Coast Eng 2006:4907-4918

Le TA, Takagi H, Heidarzadeh M, Takata Y, Takahashi A (2019) Field surveys and numerical simulation of the 2018 Typhoon Jebi: impact of high waves and storm surge in semi-enclosed Osaka Bay, Japan. Pure Appl Geophys 176(10):4139-4160

Mas E, Koshimura S, Suppasri A, Matsuoka M, Matsuyama M, Yoshii T, Jimenez C, Yamazaki F, Imamura F (2012) Developing tsunami fragility curves using remote sensing and survey data of the 2010 Chilean Tsunami in Dichato. Nat Hazards Earth Syst Sci 12(8):2689-2697

Matano H, Sekioka M (1971) Some aspects of extratropical transformation of a tropical cyclone. J Meteorol Soc Jpn Ser II 49:736-743

Paul BK (2009) Why relatively fewer people died? The case of Bangladesh's Cyclone Sidr. Nat Hazards 50(2):289-304

Rabinovich AB, Thomson RE (2007) The 26 December 2004 Sumatra tsunami: analysis of tide gauge data from the world ocean Part 1. Indian Ocean and South Africa. In: Tsunami and its hazards in the Indian and Pacific Oceans. Birkhäuser, Base, pp 261-308

Rabinovich AB, Thomson RE, Fine IV (2013) The 2010 Chilean tsunami off the west coast of Canada and the northwest coast of the United States. Pure Appl Geophys 170(9-10):1529-1565

Robertson IN, Riggs HR, Yim SC, Young YL (2007) Lessons from Hurricane Katrina storm surge on bridges and buildings. J Waterw Port Coast Ocean Eng 133(6):463-483

Shchepetkin AF, McWilliams JC (2005) The regional oceanic modeling system (ROMS): a split-explicit, free-surface, topography-following-coordinate oceanic model. Ocean Model 9(4):347-404

Shimozono T, Tajima Y, Kennedy AB, Nobuoka H, Sasaki J, Sato S (2015) Combined infragravity wave and sea-swell runup over fringing reefs by super typhoon Haiyan. J Geophys Res 120(6):4463-4486

Suppasri A, Mas E, Koshimura S, Imai K, Harada K, Imamura F (2012) Developing tsunami fragility curves from the surveyed data of the 2011 Great East Japan tsunami in Sendai and Ishinomaki plains. Coast Eng J 54(01):1250005

Synolakis CE, Bernard EN (2006) Tsunami science before and beyond Boxing Day 2004. Philos Trans R Soc Lond A 364(1845):2231-2265

Takagi H, Wu W (2016) Maximum wind radius estimated by the $50 \mathrm{kt}$ radius: improvement of storm surge forecasting over the western North Pacific. Nat Hazards Earth Syst Sci 16(3):705-717

Takagi H, Esteban M, Shibayama T, Mikami T, Matsumaru R, De Leon M, Thao ND, Oyama T, Nakamura R (2017) Track analysis, simulation, and field survey of the 2013 Typhoon Haiyan storm surge. J Flood Risk Manag 10(1):42-52

Takemi T, Ito R, Arakawa O (2016) Effects of global warming on the impacts of Typhoon Mireille (1991) in the Kyushu and Tohoku regions. Hydrol Res Lett 10(3):81-87

Tatekoji A, Nakamura R, Shibayama T (2017) Influence of historical bathymetric changes due to urbanization on the vulnerability of storm surge in Tokyo Bay. Coast Eng Proc 1(35):22

Tsuchiya Y, Kawata Y (1986) Historical study of changes in storm surge disasters in the Osaka area. Nat Disaster Sci 8(2):1-18

Tsuji Y, Satake K, Ishibe T, Kusumoto S, Harada T, Nishiyama A, Kim HY, Ueno T, Murotani S, Oki S, Sugimoto M, Tomari J, Heidarzadeh M, Watada S, Imai K, Choi BH, Yoon SB, Bae JS, Kim KO, Kim HW (2011) Field surveys of tsunami heights from the 2011 off the Pacific Coast of Tohoku, Japan Earthquake. Bull Earthq Res Inst Univ Tokyo 86:29-279

Weatherall P, Marks KM, Jakobsson M, Schmitt T, Tani S, Arndt JE, Rovere M, Chayes D, Ferrini V, Wigley R (2015) A new digital bathymetric model of the world's oceans. Earth Space Sci 2(8):331-345

Wessel P, Smith WHF (1998) New, improved version of Generic Mapping Tools released. Eos Trans AGU 79(47):579. https://doi.org/10.1029/98EO00426

Yalciner AC, Zaytsev A, Aytore B, Insel I, Heidarzadeh M, Kian R, Imamura F (2014) A possible submarine landslide and associated tsunami at the Northwest Nile Delta, Mediterranean Sea. Oceanography 27(2):68-75

Publisher's Note Springer Nature remains neutral with regard to jurisdictional claims in published maps and institutional affiliations. 